\title{
ALTERNATIVE CRIMINAL SANCTIONS IN THE CRIMINAL LEGISLATION OF MONTENEGRO
}

\author{
UDC 343.242/.244(497.16)
}

\section{Darko Radulović}

Faculty of Law, University of Montenegro, Montenegro

\begin{abstract}
The author first discusses various issues concerning the punishment of imprisonment (deprivation of liberty), especially short-term sentences of imprisonment, and cites the criminal law theories on the issue. Then, the author explains the importance of alternatives to the punishment of imprisonment and their place in the Criminal Code of Montenegro. In the context of alternative criminal sanctions, the author focuses on fines, community service order and cautionary measures (suspended sentence and judicial admonition). It is stressed that alternative criminal sanctions have a significant place in the system of criminal sanctions and may be a relevant tool for replacing short-term imprisonment sentences. The author concludes that despite a wide registry of alternative criminal sanctions, imprisonment can never be completely abolished. Yet, for some criminal offenses and some offenders, the punishment of imprisonment is inadequate and, in specific circumstances, it should better be replaced with other criminal sanctions.
\end{abstract}

Key words: Criminal Code, criminal sanctions, imprisonment (deprivation of liberty), alternative criminal sanctions, fine, community service order, suspended sentence, judicial admonition.

\section{INTRODUCTION}

The punishment of imprisonment (deprivation of liberty) was first introduced in the criminal legislation of France in the late 18th century, in response to the ferocity and cruelty of the repressive system that had previously been applied, dominated by different types of physical punishment and the death penalty with various forms of execution. Introduction and promotion of imprisonment as a form of punishment may be attributed to a number of factors. It points out to the humanistic orientation and new progressive ideas in the society of the time, which made the application of physical punishment anachronistic. As emphasized, such form of punishment was an essential need of criminal

Received February $7^{\text {th }}, 2017$ / Accepted February $24^{\text {th }}, 2017$

Corresponding author: Darko Radulović, LL.D.

Faculty of Law, University of Montenegro, Montenegro

E-mail: darko77@t-com.me 
policy, and a guarantee that the objectives of punishment would be achieved by that type of criminal sanction. In addition, according to the literature, after the earlier repressive measures it was not difficult to have the punishment of imprisonment accepted as something advanced and progressive (Eliot, 1962: 69).

In addition to these factors, it was financially significant at the time because imprisonment resulted in cheap or free labour for the society. Finally, a factor of no lesser importance was the fact that human freedom occupied a significant place on a scale of social values, and the deprivation of liberty was considered sufficient punishment for certain categories of offenders (Mlađenović-Kupčević, 1982: 152).

However, the history of punishment of deprivation of liberty is also the history of challenging this form of punishment because certain objections have been made since the very beginning of its introduction in the penal systems of European countries. The key objection is that this penalty is a crime-inducing factor given the fact that convicted offenders, who committed a wide range of criminal offenses for various motives, are mixed and serve a communal sentence of imprisonment in the same penal institutions. Such circumstances may contribute to the so-called "criminal contagion". The prison population may also include those who have better living conditions in prison than outside the correctional facility; some authors point out that imprisonment may not be a deterrent for them, but that it may even be appealing (Ignjatović, 1996:415). It was also stressed that the retributive element prevailed in the punishment of imprisonment, that it guaranteed no special prevention; as sited in literature, it could be hardly argued that prisons could be an instrument of training an offender for the social life because the prison, in itself, was a negation of social life (Barnes, Teters, 1959: 586).

Therefore, besides the short-term prison sentences, which were a stumbling block from the beginning (Lazarević, 1974), long-term imprisonment was exposed to the long blade of criticism as well. Some authors emphasized that long-term prison sentences should be reduced and left only as a substitute for death penalty (Lazarević, 1987:34). On the one hand, prison has a destructive influence on the convicted person and his/her family; on the other hand, according to some studies, there is no significant impact in the field of general prevention (Panjević, 1999:3).

This brief overview shows that there are numerous criticisms of the punishment of imprisonment, especially short-term prison sentences, which have been criticized from many different aspects: sociological, criminological, criminal and political, psychological, etc. Pinatel pointed out that all these criticisms were "expression of feelings against prison as a misconception of the $19^{\text {th }}$ century"(Pinatel, 1959:709-726).

In defence of imprisonment, other scholars emphasize that critics of this form of punishment forget, consciously or unconsciously, that offenders are excluded from society in order to be returned to society again, and kept in prison because no more suitable way and method for their re-socialization were identified (Vodopivec, 1966:77).

In addition to being under the scrutiny of individual scholars and practitioners, the punishment of imprisonment has been and still remains the subject of intensive discussions at the level of many international organizations and associations for criminal law and related sciences, and even in the United Nations through their Congress on the Prevention of Crime and the Treatment of Offenders. The Council of Europe also issued a series of documents aimed at strengthening mutual cooperation and humanization of national criminal codes; these documents prescribed legal standards for the application of alternative criminal sanctions aimed at replacing the sentences of imprisonment. 
In recent decades, modern legislation has been looking for alternatives to imprisonment which would reduce its application and eliminate its negative effects, both in respect of the offenders' re-socialization and in terms of protecting the society from crime. The criminal legislation of Montenegro has taken the same course of action as well.

\section{CONCEPT OF ALTERNATIVE CRIMINAL SANCTIONS}

Before presenting the alternatives to the deprivation of liberty prescribed under the Criminal Code of Montenegro ${ }^{1}$, some concepts of the alternative criminal sanctions will be discussed. According to a broader understanding, an alternative to imprisonment are those sanctions where the indictment or conviction leaves the possibility for offenders to spend part of the prison sentence or the entire period for which they were convicted in their communities, outside a prison establishment (Vass, 1990: 420).

According to another conception, it is considered that alternatives to deprivation of liberty are non-custodial sanctions imposed by the court when it is assessed, given the circumstances of the subjective or objective nature, that it is more reasonable to impose a non-custodial measure (Bishop, 1988: 44).

The national literature also includes different views on the issue of what can be considered as an alternative to criminal sanctions. Thus, it is stated that sanctions alternative to deprivation of liberty are considered to be alternative criminal sanctions (Stojanović, 2009: 13), but without specifying what is included in such sanctions, whereas a fine is not viewed just as an alternative to short-term imprisonment but as a form of punishment which has its autonomous place.

Some suggest that in alternative sanctions the court chooses between imprisonment and other measures, and the sentenced offenders declare whether they agree to have them pronounced; if they do not agree or fail to carry out an imposed alternative measure, it shall be replaced by imprisonment by the court decision (Ignjatović, 2008:4). This view may be challenged by saying that in the national legislation no sanction is imposed with the consent of the defendant other than the sentence of community service. Some authors believe that alternative sanctions in the first place imply an alternative to short-term punishments of imprisonment (Mrvić-Petrović, Đorđević, 1998: 96) including a fine, community service, suspended sentence and suspended sentence with supervision (Mrvić-Petrović, 2005: 57). To conclude this overview of different perspectives on the concept of alternative criminal sanctions, a standpoint that seems to be the most interesting and most acceptable is presented hereinafter. Accordingly, regarding the concept of alternative criminal sanctions, one should start from listing the criminal sanctions which are considered to be primary in criminal law, and then determine which criminal sanctions in relation to the primary ones may be considered as an alternative. As pointed out by the advocates of this view, it is sufficient to have quite a simple criterion, which is reduced to criminal sanctions laid down with each individual incrimination in a separate section of the Criminal Code; thus, the primary criminal sanctions shall be penalties (primarily the sentence of imprisonment) and a fine (in some cases). In such a case, the general part of the Criminal Code sets out certain alternatives to the primary criminal sanction (Škulić, 2014:251). According to this criterion, alternative criminal sanctions would include community service, suspended sentence and

\footnotetext{
${ }^{1}$ Criminal Code of Montenegro, Official Gazette of Montenegro, 70/03, 47/06, 40/08, 25/10, 32/11, 40/13,
} 
judicial admonition, but not a fine, given the fact that a sentence of imprisonment and a fine are alternative forms of punishment in cases where, as prescribed in a separate section of this Code, the punishment for the committed criminal offence may be either a fine or a term of imprisonment, alternatively.

However, regardless of the different perspectives on the issue of what is considered an alternative to criminal sanctions, in the process of imposing these alternative sanctions it is essential to bear in mind the personality of the criminal offender, the nature of crime, and the circumstances of the committed criminal offense.

\section{FINES}

Fine is among the oldest penalties in the system of criminal sanctions. The forerunner of a fine is compensation, according to which the offender was required to pay a certain sum of money or other value to the injured party or their family because of the committed criminal offense and, thus, neutralize the vengeful motives of the injured party or their family. Later, with the development of social and economic relations, a fine distanced itself from such compensation and gradually acquired a fiscal character. At the end of the $18^{\text {th }}$ century, it became an instrument for combating crime, and a viable alternative to short-term prison sentences after the introduction of penalties related to deprivation of liberty. However, this penalty was exposed to certain criticism, ranging from claims that it was purely retributive, with no correctional treatment against the perpetrator of crime, that it affected not only the offenders but also their families, that it unequally affected the rich and the poor, etc.

However, regardless of all the objections, it is nowadays one of the most frequently applied criminal sanctions, which has an autonomous place in the system of criminal sanctions, and it is no longer seen only as an alternative to short-term prison sentences (Stojanović, 2008: 280). In the area of petty and minor crimes, fine has totally replaced the sentence of imprisonment in some countries (Hassemer, 1990: 298).

In order to eliminate or mitigate the disadvantages of fines, criminal legislations have developed certain systems for prescribing and determining fines. Accordingly, in the contemporary comparative law, there is now a system of fixed fine amounts, the system of day-fines, and a fine which is based on the system of "average personal income". The Criminal Code of Montenegro adopted a mixed system, which includes the system of fixed fines (Article 39) and the system of fines in daily amounts (Article 40). Article 39(1) prescribes a general minimum fine (€200) and two general maximum amounts ( $€ 20,000$ or $€ 100,000$ for criminal offenses motivated by greed).

The separate section of the Criminal Code prescribes no specific minimum and specific maximum fine, except in case a criminal offence is punishable only by a fine (which only applies to three crimes). Therefore, in Article 39(2), the legislator introduced a novelty, the so-called ranges of fines related to the gravity of the crime expressed by the length of the pronounced term of imprisonment, which serves as a point of reference for prescribing a relevant fine. In this regard, the fine as principal punishment shall be imposed in the following amounts: 1) up to $€ 2,000$ for criminal offenses punishable by imprisonment of up to 3 months; 2) from $€ 400$ to $€ 4,000$ for criminal offenses punishable by imprisonment of up to 6 months; 3) from $€ 600$ to $€ 8,000$ for criminal offenses punishable by imprisonment of up to one year; 4) from $€ 800$ to $€ 16,000$ for criminal offenses punishable by imprisonment of up to 
two years; 5) at least $€ 1,200$ for criminal offenses punishable by imprisonment of up to four years; 6) at least $€ 1,200$ for criminal offenses for which a fine is prescribed as the only punishment.

Although the legislator established the rule in Article 40(2) that in the course of sentencing the court shall specifically consider the financial situation of the offender, that rule was largely devalued by introducing the rules under Article 39(2), i.e. linking the amount of the fine to the gravity of the offense. According to some authors, this may be interpreted only as the legislator's assessment that lenient sentences had already been pronounced and that this solution was aimed at urging the courts to impose higheramount fines (Lazarević, 2010:124).

The general rule is that a fine is imposed for criminal offenses for which it is prescribed. However, Article 39(3) of the Criminal Code provided for an exception to the rule, given that a fine may be imposed as an accessory sanction for criminal offenses motivated by greed, even when it is not prescribed by law or when the law stipulates that the perpetrator shall be punished by imprisonment or a fine, and imprisonment is imposed as the principal punishment by the court. This provision is justified because the legislator cannot predict in advance which criminal offence may be committed for gain in order to prescribe the related fine, and such a motif (greed) of the offender has to be financially penalized as well.

The system of fine in daily amounts is provided for in Article 40 of the Criminal Code. Such a fine may be imposed if it is possible to determine the revenues and expenditures of the offender. The number of daily amounts shall not be less than 10 or exceed 360 days, and it is assessed according to the general rules on sentencing. A daily amount of a fine is determined by dividing the difference between the offender's revenues and necessary expenditures in the previous calendar year by the number of days in the year, provided that the daily amount of the imposed fine shall not be less than $€ 5$ or more than $€ 1,000$ per day. The amount of a fine shall be calculated by the court, by multiplying the assessed number of daily amounts with the established value of a single daily amount. This system ensures that different amounts of fine may be imposed on the perpetrators of the same criminal offense who may have a different financial standing, under similar circumstances which are assessed in the sentencing process.

The main issue in the application of this system is how to accurately determine the income of the offender in local circumstances, notwithstanding the fact that Article 40(5) stipulates that, in order to determine the value of the daily amount, the court may request information from banks and other financial institutions, government authorities and other legal entities who are obliged to submit the requested data and shall not invoke the protection of commercial and other secrets. In addition, the formal image of income and assets of almost every individual is essentially different from the actual situation and the amount of income generated by an individual.

Although both systems for determining fines have an equal standing in the Criminal Code, the system of fixed amounts is exclusively applied in practice, which may lead to the conclusion that the system of fixed amounts is primary while the system of daily amounts is subsidiary (Stojanović, 2010:170).

\section{COMMUNITY SERVICE ORDER}

The community service order is a sanction which is gaining increasing importance in modern criminal legislation and has been increasingly supported in criminal law literature. Yet, in comparative law, its normative frame differs depending on the state-specific 
legislation. In some jurisdictions, it is an independent punishment; in others, it is regarded as a substitute for imprisonment or treated as a condition for imposing some other criminal sanctions. Community service is a typical alternative criminal sanction, and the positive experiences in its application in other countries were the reason for introducing this sanctions in the Criminal Code of Montenegro in 2003. It may be imposed only as principal punishment or as a substitute for unpaid fine. It may be imposed for criminal offenses punishable by a fine or a term of imprisonment of up to five years. In addition, this form of punishment is highly specific because the consent of an offender is required, given the fact that forced labour is prohibited according to international legal documents. When it comes to criminal offences punishable by a fine or up to five years' imprisonment, three options are available to the court: to impose a fine, a sentence of imprisonment, or the community service order with the consent of the offender. This further means that the court will first evaluate whether it is necessary to impose a sentence of imprisonment or possibly a fine; if it is estimated, taking into account the gravity of the offense and the personality of the offender, that it is not necessary to impose a prison sentence or a fine in order to achieve the purpose of punishment, a sentence of community service order shall be pronounced (Lazarević, 2005:182).

The gravity of crime, which is reflected in the prescribed amount of fine, is the legal ground for pronouncing a sentence of community service order, and yet the court will take account of the type of criminal offense in question, as well as the personality of the offender. Article 41 stipulates that community service order shall not be shorter than 60 hours or longer than 360 hours; it is determined for a period that shall not be shorter than 30 days or longer than 6 months, and it shall not be longer than 60 hours in one month. In case the offender fails to perform the community service order, the sentence shall be substituted by a sentence of imprisonment in such a way that each 60 hours of community service shall be replaced by one-month imprisonment sentence.

The content of community service is generally defined in Article 41, listing three essential elements: the community service has to involve socially beneficial work, which does not offend the human dignity and is not done for the purpose of gaining profit. It should create the offender's feeling that his/her service and the positive attitude towards others may compensate for the evil done by committing a crime (Stojanović, 2005:17). Some authors are of the opinion that the Code should provide for the possibility of professional training of the convicted offenders for a profession during the execution of the sentence of community service order (Škulić, 2014:251).

Since its introduction in the criminal legislation until today, the penalty of community service order has met the growing support in the scientific and professional community. It has many advantages compared to imprisonment because the convicted offender is not separated from the family and home, and therefore the family as the basic oasis of social existence remains preserved both in terms of quantity and quality. If the offender is employed, there is no termination of employment, which is very important in these days of high unemployment. On a psychological level, this sentence creates in the convicted person a sense of integration in the community, rather than the feeling of rejection and being unwelcome. The community, which often believes that delinquents should be isolated, begins to change its attitude towards them. Given the fact that such a perpetrator performs everyday tasks, takes care of his family and gives up his/her leisure time to do voluntary service in the public interest, in the eyes of the community it creates the image of a man who should be given an opportunity to become a beneficial and equal member of the community, without being isolated. 
Despite all the benefits that are attributed to this sanction, it has also been subject to certain objections, which mostly focus on practical issues: where to provide community service, how to supervise the provided service, and the like. Yet, the most important concern is to ensure that this penalty is actually applied in practice, given that experience shows that it is rarely used.

\section{WARNING MEASURES}

Warning measures have an increasingly important position in modern criminal law or crime suppression policy. These sanctions do not involve imprisonment but the criminal offenders' adequate treatment in relevant institutions without imprisonment. They include different measures of warning. For a long period of time, many national legislations invariably recognized and used different forms of suspended sentence as warning measures, while only a small number of countries envisaged judicial admonition as a warning in their system of criminal sanctions. Considering the criticism of short-term prison sentence, warning measures emerged as a result of knowledge that in some cases the state reaction to certain anti-social behaviour may include issuing a warning or a warning involving a threat of imprisonment, which may be sufficient for accomplishing the purpose of criminal punishment and deterring the offender from further commission of crime in particular. In such criminal policies, the sentence of imprisonment should be the last resort (ultima ratio), meaning that no stricter sanction shall be applied when the general purpose of punishment may be achieved by a milder sanction (Stojanović, 2008:307).

\section{1) Suspended sentence}

Suspended sentence as a warning measure is a special type of criminal sanction which is imposed in criminal proceedings after the court has found the offender guilty of the committed crime; it entails a warning to the offender not to commit a criminal offense along with a threat of being sentenced to a term of imprisonment in case of reoffending. To a certain extent, the concept of a suspended sentence envisaged in the Criminal Code of Montenegro rests on the solutions provided in the Anglo-American law and the Europeancontinental law. As in the UK legislation, it is an independent criminal sanction which implies the postponement of sentencing, and its basic content is a warning with a threat of imprisonment. It is close to the continental model of a suspended sentence as it is closely related to punishment and entails a specific threat of a precisely determined sanction.

Suspended sentence is imposed on the offender by the court as a form of punishment, and the court concurrently orders that it will not be executed if the convicted person does not commit another criminal offense during the (probation) period set by the court, which may not be shorter than one or longer than five years.

A suspended sentence may be imposed only when both objective and subjective conditions have been fulfilled. The objective condition is linked to the gravity of the offense, which is clearly reflected in the sentence; thus, a suspended sentence may be imposed when in the specific case the offender has been sentenced to a term of imprisonment of up to two years. The punishment is first determined under the general sentencing rules. Its application is excluded when it comes to serious crimes, as Article 54(2) reads that the suspended sentence may not be imposed for criminal offences punishable by a sentence of imprisonment of ten years or more. The subjective condition is to confirm that the perpetrator is guilty, that more 
than five years have passed from the date of the offender's final conviction by which the offender was sentenced for intentional criminal offense, and that the court is convinced that the suspended sentence will influence the perpetrator not to commit crimes in the future. A suspended sentence shall not be imposed on the offender who has already been imposed two prior suspended sentences.

In deciding whether to impose a suspended sentence, the court shall, taking into account the purpose of the suspended sentence, pay special attention to the personality of offenders, their past conduct and behaviour after the commission of the criminal offence, the degree of culpability and other circumstances under which the offense has been committed (Article 54 (4)). After imposing a suspended sentence, the court determines the specific punishment, which corresponds to the legal nature of the suspended sentence as an independent criminal sanction. Irrespective of whether a convicted person has committed a single crime or a number of criminal offences, the determined punishment for all crimes shall not exceed a period of two years. The suspended sentence may only be related to a sentence of imprisonment and it does not apply to cases involving a fine.

The introduction of this model of suspended sentence has given rise to the question whether the determined punishment (sentence of imprisonment) should be communicated to the convicted person while imposing a suspended sentence. According to some opinions, if the determined punishment is communicated, then the effect of such a suspended sentence is the same as the effect of the suspended sentence where the punishment is pronounced; thus, in case of revocation of the suspended sentence, the determined punishment would be communicated only on two occasions: first, at the time of imposing the suspended sentence and, second, at the time of revoking the suspended sentence (Bačić, 1989:46). However, the purpose of a suspended sentence and other provisions regulating the suspended sentence implies that the determined punishment must be communicated to the convicted, because punishment makes up the content of the suspended sentence. In case the defendant is only informed about the imposed suspended sentence, without being notified of the determined punishment, the offender would not be aware of the threatened term of imprisonment.

In addition to the offender's principal obligation not to commit another crime, the Criminal Code provides for the possibility of imposing other obligations on the person subject to the suspended sentence, specifically including the obligation to return the property and proceeds of crime, to compensate for the damage caused by the commission of the criminal offence, and all other obligations that may be prescribed by law.

In addition to ordinary suspended sentence, the legislator has envisaged a suspended sentence with protective supervision (Article 59), which is a combination of the common law and continental type of suspended sentence. This type of suspended sentence implies placing the offender under protective supervision for a particular period, whereby supervision encompasses measures of assistance, care and protection stipulated by law. The content of protective supervision is defined in Article 61, including a number of related obligations that may be imposed on the offender:

1. reporting to the competent authority responsible for the execution of protective supervision within the time limits specified by that authority;

2. relevant vocational training of the offender for a particular occupation,

3. accepting a job corresponding to the offender's abilities and preferences;

4. meeting the obligation to support family, take care of children and their upbringing, and perform other family duties;

5. refraining from visiting certain places, bars or events, if it may be an opportunity or incentive for re-commission of criminal offenses; 
6. timely notification of the change of residence, address or job;

7. refraining from the use of drugs or alcoholic beverages;

8. treatment in a relevant medical institution;

9. visiting specific professional and other counselling centres or institutions, and following their instructions;

10. eliminating or mitigating the damage caused by the criminal offense, particularly reconciliation with the injured party/victim of the committed criminal offense.

It can be concluded from the above registry of obligations that some of them are imposed for the purpose of controlling the offender's conduct while others are aimed at assisting the offender, although in most cases it is difficult to clearly specify the limits of obligations aimed at protecting and those aimed at assisting the convicted person. When setting up these obligations, the aim is to achieve both goals. Given the legal nature and purpose of this type of suspended sentence, there is an opinion in literature that there is one obligation that must always be imposed, alongside with any of the other nine obligations; as a rule, it is the offender's obligation to regularly report to the competent authority responsible for the execution of protective supervision within the time limits specified by that authority (Stojanović, 2010: 227).

In practice, case law shows that the suspended sentence is the most frequently imposed criminal sanction as a substitute for imprisonment, while the suspended sentence with protective supervision is hardly ever applied.

\section{2) Judicial admonition}

Judicial admonition is the mildest criminal sanction against adult criminal offenders; in terms of content, it is close to correctional measures imposed on minors and its ultimate goal is the educational effect. As a criminal sanction sui generis (Bulatović, 1974), it was first introduced in the Yugoslav criminal legislation by the Act on Amendments to the Criminal Code of 30 June 1959. The provisions on judicial admonition were transferred to the Criminal Code of Montenegro (2003), which introduced the offender's conduct and attitude to the victim as a circumstance that is assessed in imposing judicial admonition. A judicial admonition may be imposed provided that the following two conditions have been fulfilled cumulatively: a) it is related to a criminal offense punishable by a term of imprisonment of up to one year or a fine; and b) the crime was committed under such extenuating circumstances that may be qualified as a minor or petty crime. The first condition is objective and the prescribed punishment expresses the abstract gravity of the offense. The second condition is both objective and subjective in nature because specific danger is expressed through the specific circumstances related to the offender. In addition, Article 65(2) stipulates that judicial admonition may be imposed for certain criminal offenses and under the conditions provided by law even in cases where the prescribed punishment is a term of imprisonment not exceeding three years. The separate section of the Criminal Code includes an option to impose a judicial admonition (as prescribed by law) for certain crimes committed in exceptional circumstances.

The second condition, which implies that the criminal offense was committed under such extenuating circumstances that may qualify it as a minor/petty crime, is assessed according to the circumstances that are otherwise assessed in the process of sentencing, but it is necessary that they are extenuating in terms of content. In criminal law theory, it is considered to be closest to the circumstances where the gravity of the criminal offence 
is measured by the intensity of the consequences, the specific circumstances under which the crime was committed, and the personality of the perpetrator, whereby the committed criminal offence may be below the common average for a specific crime but still may not be qualified as a minor crime (Bejatović, 1986:193). Judicial admonition may be imposed for several criminal offenses committed concurrently, provided that both conditions for imposing a judicial admonition existed for each offense individually.

Judicial admonition is a social and ethical reprimand for the committed criminal offense; concurrently, the perpetrator is warned that more stringent criminal sanctions may be expected if the crime committed again. Admonition is a socio-ethical assessment of a crime which expresses the community's condemnation of such behaviour; the warning shows the attitude and determination of the society not to tolerate such behaviour. Certainly, the threat of a more rigorous sentence refers to a new criminal offense, not the offense for which the judicial admonition is imposed. Such content of judicial admonition determines its direct criminalpolitical goals which are intended to be achieved by its application; basically, the ultimate goal is special prevention. Despite all the benefits provided by this criminal sanction, which may be used as an alternative not only to the sentence of imprisonment but also to fine, this alternative criminal sanction is rarely applied in practice.

\section{CONCLUSION}

Alternative criminal sanctions have a significant place in the system of criminal sanctions and may be a relevant tool for replacing short-term imprisonment sentences. Despite a wide registry of alternative criminal sanctions, imprisonment can never be completely abolished. Yet, the sentence of imprisonment is inadequate for some criminal offenses and some offenders, and in specific circumstances, it should be replaced with alternative criminal sanctions. In this context, we have examined the alternatives to the punishment of imprisonment: fines, community service order and cautionary measures (suspended sentence and judicial admonition) and their position in the Criminal Code of Montenegro. Considering that case law has shown that many of these alternative criminal sanctions are rarely or hardly ever used in judicial practice, it is essential to ensure their actual application, particularly bearing in mind the personality of the criminal offender, the nature of crime, and the circumstances of the committed criminal offense. Apart from eliminating the negative effects of imprisonment on the convicted person, these alternative forms of punishment would provide for general prevention and promote the concept of offenders' re-socialization and re-integration into the local community.

\section{REFERENCES}

Bačić, Franjo (1989). Uslovna osuda u jugoslovenskom krivičnom zakonodavstvu, (A suspended sentence in the Yugoslav criminal legislation), Pravna misao, br. 5-6, 1989: 46.

Barnes, H.;Teters, N. (1959). New Horizons in Criminology, 1959: 586.

Bejatović, Stanko (1986). Mjesto i značaj uslovne osude i sudske opomene u sistemu krivičnih sankcija, (The place and significance of a suspended sentence and judicial admonition in the system of criminal sanctions), Jugoslovenska revija za kriminologiju i krivično pravo, br. 1-2, $1986: 193$.

Bishop, Norman (1988). Non-Custodial Alternatives in Europe, Helsinki Institute for Crime prevention and control affiliated with the United Nations 1988, No 14, p. 44.

Bulatović, Žarko (1974). Pravna priroda sudske opomene, Legal nature of admonition, Anali Pravnog fakulteta u Beogradu, No. 4, Beograd, 1974. 
Eliot, Mabel (1962). Crime in Modern Society (translation), Sarajevo, 1962: 69.

Hassemer W., Einführung in die Grundlagen des Strafrechts, 2. Anflage, Munchen, 1990. p. 298, cited by Zoran Stojanovic, u: Krivično pravo, (Criminal Law) Podgorica, 2008, p. 280.

Ignjatović, Đorđe (1996). Savremeni oblici zamene kazne zatvora, (Modern ways of replacing the prison sentence), Pravni život, br. 9, 1996, p. 415.

Ignjatović, Đorđe (2008). Pravo izvršenja krivičnih sankcija, (Legislation on the execution of criminal sanctions), Pravni fakultet u Beogradu, 2008, p. 4.

Lazarević, Desanka (1974). Kratke kazne zatvora (Short-term prison sentences), Beograd, 1974.

Lazarević, Ljubiša (et al.) (2010). Komentar Krivičnog zakonika Crne Gore (Commentary on the Criminal Code of Montenegro), Tivat, 2010, p. 124

Lazarević, Ljubiša (2005). Komentar Krivičnog zakonika (Commentary on the Criminal Code), Belgrade

Lazarević, Ljubiša (1987). Sistem krivičnih sankcija (The system of criminal sanctions), Jugoslovenska revija za kriminologiju i krivično pravo, No. 2, Beograd, 1987, p. 34.

Mlađenovic-Kupčević, Rajka (1982).Osnovi penologije (Introduction to Penology), Sarajevo, p. 152.

Mrvić-Petrović, Nataša (2005). "Alternativne krivične sankcije"- Alternative zatvorskim kaznama ("Alternative criminal sanctions" - Alternatives to prison sentences), Beograd, 2005, p. 57.

Mrvić-Petrović, N.; Đordjevic, Đ. (1998). Moć i nemoć kazne (The Power and Constraints of Punishment), Belgrade, 1998, p. 96.

Krivični zakonik Crne Gore (Criminal Code of Montenegro), "Službeni list Republike Crne Gore", br. 70/03, 47/06, 40/08, 25/10, 32/11 i 40/13

Panjević, Milorad (1999). Savremene alternative kazni zatvora (Modern Alternatives to Imprisonment), Master thesis, Kragujevac, 1999, p. 3.

Pinatel, Jan (1959). Les divers conceptions de la science penitentiare, Revue science criminalle et de droit penal compare, Paris, 1959, p. 709-726, No. 3.

Škulić, Milan (2014). Alternativne krivične sankcije, (Alternative Criminal Sanctions), U: Zbornik radova "Kaznena politika kao instrument državne politike na kriminalitet", Banja Luka, 2014, p. 251, 256.

Stojanović, Zoran (2010), Komentar Krivičnog zakonika (Commentary on the Criminal Code), Podgorica, 2010, p. 170,227 ,

Stojanović, Zoran (2008). Krivično pravo (Criminal Law), Podgorica, 2008, p. 280, 307

Stojanović, Z. (2005). Osnovne koncepcije u predlogu Krivičnog zakonika Srbije i Krivičnog zakonika Crne Gore, (Basic concepts in the draft Criminal Code of Serbia and the Criminal Code of Montenegro), Revija za kriminologiju i krivično pravo, No. 1, 2005, p. 17.

Stojanović, Z. (2009). Pojednostavljene forme postupanja u krivičnim stvarima i alternativne krivične sankcije (Simplified forms of procedure in criminal matters and alternative criminal sanctions), U: Zbornik radova "Pojednostavljene forme postupanja u krivičnim stvarima i alternativne krivične sankcije", Zlatibor, 2009, p. 13.

Vass, A. (1990). Alternatives to Prison: Punishment, Custody and the Community, London, 1990, p. 420.

Vodopivec, Katja (1966). Kriminologija (Criminology), Volume I, Zagreb, 1966, p. 77.

\section{ALTERNATIVNE KRIVIČNE SANKCIJE U KRIVIČNOM ZAKONODAVSTVU CRNE GORE}

Autor na početku rada govori o različitim problemima kazni lišenja slobode, naročito kratkotrajne kazne lišenja slobode $i$ navodi stanovišta krivično-pravne teorije o ovom problemu. Potom izlaže o značaju alternativa kazni lišenja slobode i o njihovom mjestu u Krivičnom zakoniku Crne Gore. U okviru alternativnih krivičnih sankcija govori o novčanoj kazni, kazni rada u javnom interesu i mjerama upozorenja (uslovnoj osudi i sudskoj opomeni). Naglašava da alternativne krivične sankcije imaju značajno mjesto u sistemu krivičnih sankcija i pogodno su sredstvo za zamjenu kratkotrajnih kazni lišenja slobode. Autor zaključuje da i pored širokog registra alternativnih krivičnih sankcija, kazna zatvora ne može nikad biti potpuno potisnuta, ali u pogledu nekih krivičnih djela i nekih učinilaca, kazna zatvora nije adekvatna i bolje je, kada za to postoje uslovi, zamijeniti drugim krivičnim sankcijama.

Ključne reči: Krivični zakonik, krivične sankcije, kazna lišenja slobode, alternativne krivične sankcije, novčana kazna, rad u javnom interesu, uslovna osuda, sudska opomena

Proofreding and translation: Gordana Ignjatović 